\title{
Assessment of symptoms of depression, anxiety and stress in academics from higher education institutions under conditions of social distance
}

Avaliação dos sintomas de depressão, ansiedade e estresse em acadêmicos de instituições de ensino superior sob condições de distanciamento social

Ecaluación de síntomas de depresión, ansiedad y estrés en académicos de instituciones de educación superior en condiciones de distancia social

Julia Lazarin de Oliveira ORCID: https://orcid.org/0000-0002-7183-4876 Centro Universitário Sociesc, Brazil

E-mail: julialazarin@outlook.com

Danielle Cristhine Brígido

ORCID: https://orcid.org/0000-0003-2736-9978 Centro Universitário Sociesc, Brazil E-mail: danibrgd@gmail.com

Ricardo Paulino dos Santos ORCID: https://orcid.org/0000-0002-5645-2933 Centro Universitário Sociesc, Brazil E-mail: ricardups28@gmail.com

Claudia Daiana Borges ORCID: https://orcid.org/0000-0003-2060-0014 Centro Universitário Sociesc, Brazil

E-mail: claudia.borges@unisociesc.com.br Caio Cesar Sestile ORCID: https://orcid.org/0000-0002-8323-9847 Centro Universitário Sociesc, Brazil E-mail: caiosestile86@gmail.com

Priscila Batista da Rosa ORCID: https://orcid.org/0000-0003-2833-2296 Centro Universitário Sociesc, Brazil E-mail: priscila.rosa@unisociesc.com.br

Adrielli Tenfen Voltolini

ORCID: https://orcid.org/0000-0003-3554-2152 Centro Universitário Sociesc, Brazil

E-mail: adrielli.voltolini@unisociesc.com.br Vivian Binder Neis ORCID: https://orcid.org/0000-0001-6328-431X Centro Universitário Sociesc, Brazil E-mail: vivianbneis@gmail.com

\begin{abstract}
Mood disorders are among the most prevalent health problems affecting the young adult population, especially academics of higher education. This scenario may be even more evident with the social isolation related to COVID19. The aim of this study was to investigate symptoms of stress, depression and anxiety in academics from private institutions of higher education, under social isolation. The study was performed using questionnaires to obtain socioeconomic data and the Anxiety, Depression and Stress Scale (DASS-21), using an online platform. The results demonstrated that most participants had symptoms of stress, anxiety or depression. People with mood disorders had severe scores on the DASS-21. In addition, there was a higher prevalence of severe and extremely severe symptoms in females when compared to males. Finally, there was a negative correlation with age, demonstrating that, as younger, higher the score. The participants had significant scores of mood disorders probably because the majority work and study. In addition, they probably increase the susceptibility to these conditions with COVID-19 pandemic. The predominant age corresponds to the so-called emerging adult phase and the majority of women is probably related to the fact that most health sciences courses participated in the research and had predominantly women.
\end{abstract}

Keywords: Depression; Mood disorders; Social isolation; Anxiety; Young adult. 


\begin{abstract}
Resumo
Transtornos de humor estão entre os problemas de saúde mais prevalentes que afetam a população jovem adulta, principalmente os acadêmicos de ensino superior. Esse cenário pode ser ainda mais evidente com o isolamento social relacionado ao COVID-19. O objetivo deste estudo foi investigar os sintomas de estresse, depressão e ansiedade em acadêmicos de instituições privadas de ensino superior, sob condições de isolamento social. O estudo foi realizado por meio de questionários para obtenção de dados socioeconômicos e da Escala de Ansiedade, Depressão e Estresse (DASS21), em plataforma online. Os resultados demonstraram que a maioria dos participantes apresentava sintomas estresse, ansiedade ou depressão. Pessoas com transtornos de humor tiveram pontuações graves no DASS-21. Além disso, houve maior prevalência de sintomas graves e extremamente graves no sexo feminino quando comparado ao masculino. Por fim, houve correlação negativa com a idade, demonstrando que quanto mais jovem, maior o score. Os participantes apresentaram scores significativos de transtornos de humor, provavelmente porque a maioria trabalha e estuda. Além disso, eles provavelmente aumentam a suscetibilidade a essas condições com a pandemia de COVID-19. A idade predominante corresponde à chamada fase adulta emergente e a maioria das mulheres, provavelmente está relacionada ao fato do grande número de participação dos cursos de ciências da saúde e estes terem como predominância o sexo feminino.
\end{abstract}

Palavras-chave: Depressão; Transtornos de humor; Isolamento social; Ansiedade; Adulto jovem.

\begin{abstract}
Resumen
Los trastornos del estado de ánimo se encuentran entre los problemas de salud más prevalentes que afectan a la población adulta joven, en particular a los académicos de educación superior. Este escenario puede ser aún más evidente con el aislamiento social relacionado con COVID-19. El objetivo de este estudio fue investigar los síntomas de estrés, depresión y ansiedad en estudiantes de instituciones privadas de educación superior, en condiciones de aislamiento social. El estudio se realizó mediante cuestionarios para la obtención de datos socioeconómicos y la Escala de Ansiedad, Depresión y Estrés (DASS-21), en una plataforma online. Los resultados mostraron que la mayoría de los participantes presentaban síntomas de estrés, ansiedad o depresión. Las personas con trastornos del estado de ánimo tenían puntuaciones graves en el DASS-21. Además, hubo una mayor prevalencia de síntomas graves y extremadamente graves en las mujeres en comparación con los hombres. Finalmente, hubo una correlación negativa con la edad, mostrando que cuanto más joven, mayor es la puntuación. Los participantes obtuvieron puntuaciones significativas para los trastornos del estado de ánimo, probablemente porque la mayoría trabaja y estudia. Además, es probable que aumenten la susceptibilidad a estas afecciones con la pandemia de COVID-19. La edad predominante corresponde a la llamada fase adulta emergente y la mayoría de las mujeres probablemente estén relacionadas con el hecho de que la gran cantidad de participación en los cursos de ciencias de la salud es predominantemente femenina.

Palabras clave: Depresión; Trastornos del estado de ánimo; Aislamiento social; Ansiedad; Adulto joven.
\end{abstract}

\title{
1. Introduction
}

The novel coronavirus disease, designated as COVID-19 by the World Health Organization (WHO), originated in Wuhan, China was characterized as a pandemic, since it affected countries worldwide (Huang and Zhao, 2020). The latest WHO report, published on 29 June 2021, confirmed 181.007.816 cases and 3.927.222 deaths. In Brazil, it was notified until the present data, 18.420 .598 cases and 513.474 deaths.

In this context, the Ministry of Health recommended for the population the social distancing as a COVID-19 dissemination prevention measure (Brazil, 2020). This social distancing refers to the effort to reduce contacts and physical approach between people (Wilder-Smith \& Freedman, 2020). However, studies have demonstrated psychological consequences of this mass confinement such as higher rate of anxiety, depression, alcohol use (Ahmed et al., 2020), loneliness and anger, stress, irritability, insomnia and symptoms of post-traumatic stress (Xiang et al., 2019). In addition, stress due the uncertain incubation period of the virus, alarming news, dissemination of false and scientifically unfounded information, financial losses and difficulty securing medical care and medications can affect the mental health of individuals during this pandemic episode (Ornell et al., 2020; Shigemura et al., 2020) since induces fear and anxiety (Dong and Bouey, 2020). Psychological consequences resulting from social distancing are quite worrying since psychological impacts can be more lasting and prevalent than COVID-19 itself (Ornell et al. 2020). Symptoms of major depressive disorder, anxiety and stress disorders in the face of the pandemic have been identified in the general population (Wang et al., 2020), in addition to cases of suicide potentially linked to the psychological impacts of COVID-19 in some countries (Jung \& Jun 2020). 
Mood disorders lead to negative effects in quality of health and life, contributing to years lived with disability (Barros et al., 2019; Whiteford et al., 2010). The symptoms observed in depressive and anxiety disorders include sadness, irritability, excessive fear, shortness of breath, agitation, loss of libido, insomnia, lack of concentration and weight change, which may cause an impact in people's lives (Craske et al. 2017). Several studies demonstrated a high prevalence of mood disorders among university students (Nyer et al., 2014; Wong et al., 2013). Data from literature shows that about 15 to $25 \%$ of academics present mood disorders (Adewuya et al., 2006; Cavestro \& Rocha, 2006), which may be related to high levels of stress (Duailibi et al. 2014). This high prevalence of mood disorders in this population could be related to academic pressures, irregular sleep, extracurricular activities and family responsibilities (Adewuya et al. 2006, Eisenberg et al., 2007).

It's important to highlight that the presence of mood disorders in higher education students may be even more evident considering the current scenario. In fact, in periods of social isolation, the incidence or worsening of these conditions tend to increase (Barros et al., 2020) especially considering that some groups may be more vulnerable than others to the psychosocial effects of pandemics.

Thus, considering the susceptibility of students to stress and mood disorders and the high prevalence of this conditions in this population, in addition to the social distancing as a protective measure against COVID-19, the present study aimed to identify symptoms related to mood disorders within the university context, given this situation of social isolation, which can be seen as a very important risk factor for the development of these disorders. Data collection is essential for the creation of intervention and prevention strategies for the symptoms of mood disorders within the current scenario.

\section{Methods}

\subsection{Characterization of the study}

A cross-sectional, descriptive, and quantitative study was carried out. The descriptive research identified characteristics of the object and relates the existing variables in the research problem (Gil, 2002). Thus, in this study was investigate the quality of life, as well as depressive and anxiety symptoms in students from private higher education institutions, in each situation, which in this case was social isolation.

\subsection{Participants}

A total of 503 graduated students from private teaching institutions participated in the following survey. All of them agreed to participate in this research and signed the Informed Consent Form. For the participant's selection, a sample calculation was performed based on the number of academics from the institutions, to estimate a significant number.

\subsection{Questionnaires}

To characterize the research population, data such as sex, age, marital status, income, course, and the stage of graduation were collected through a socio-demographic questionnaire. To identify the prevalence of anxiety, depression and stress symptoms, the Anxiety, Depression and Stress Scale DASS-21, was used. This scale has been validated in the Brazilian context (Vignola and Tucci, 2014) and already been used in other studies with Brazilian University students, confirming the action of its validity and reliability among this sample (Borges et al., 2017; Martins et al., 2019). It contains 21 items that assess the presence of symptoms of anxiety, depression, and stress in the last week. Among the benefits of using this scale is the fact that it is easy to apply and because it is succinct, it does not cause excessive tiredness to the participants. It was described in the guidelines that respondents should consider the period of isolation that each person remained in this condition. 


\subsection{Procedures for data collection and analysis}

The instruments were applied virtually, using the Google forms platform, which was available during 2020, August. The researchers did not have access to the names of the participants. For data analysis, these will be organized in tables using Office 365, Excel program and after analyzed through correlation analysis of $\mathrm{T}$ test or ANOVA, when applicable, using a statistical program (Figure 1).

Figure 1. Development of the COVID-19 Epidemic.

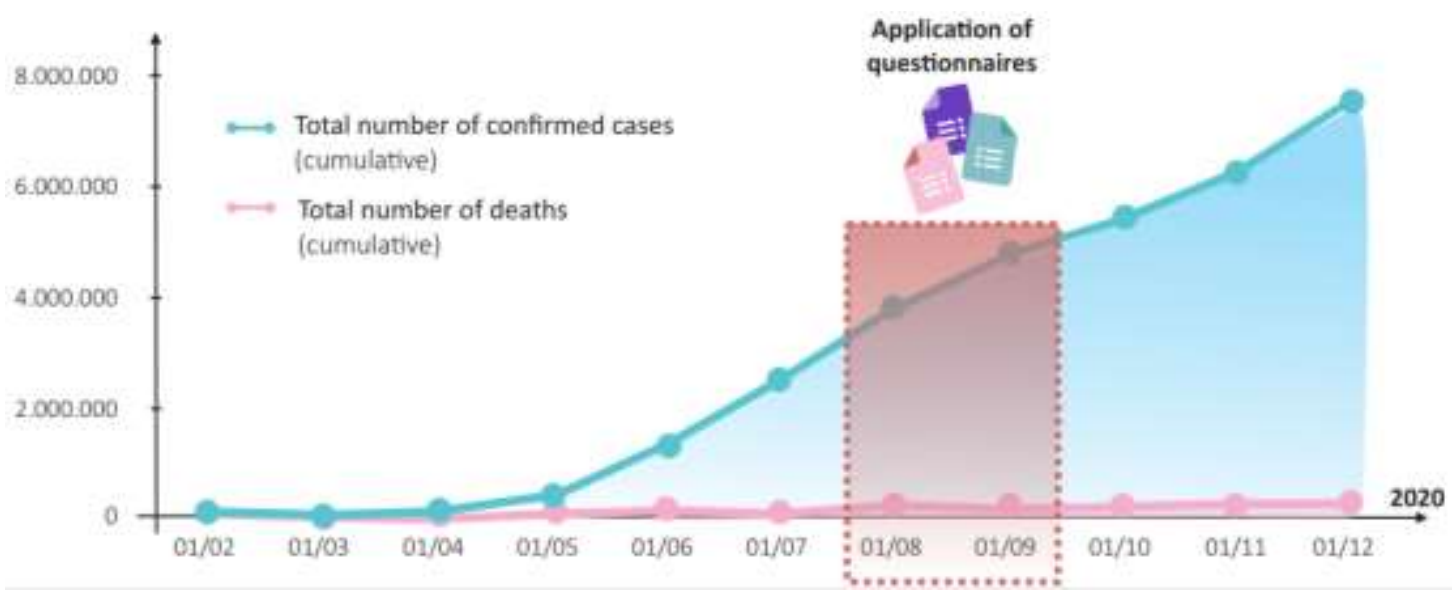

Legend: The timeline represents the period that the survey was conducted during the progress of the pandemic. The instruments were applied virtually, using the Google forms platform, which was available during 2020, August. Source: Authors (2021).

\subsection{Ethical Procedures}

The research project was approved by the Ethical Committee under protocol number: 4.241.483. Participation in the research was only allowed after the consent and signature of the informed consent by the voluntary participation of the research. The present study followed the precepts of the Code of ethics for research with human beings, according to 466/2012 resolution, guaranteeing the respect and autonomy of the participants, justice and equity (Brasil, 2012).

\section{Results}

\subsection{Description of the sample population}

A total of 503 undergraduate students from private educational institutions, distributed throughout Brazil, participated in this study. Data of socio-demographic are demonstrated in Table 1. 
Research, Society and Development, v. 10, n. 16, e548101624068, 2021

(CC BY 4.0) | ISSN 2525-3409 | DOI: http://dx.doi.org/10.33448/rsd-v10i16.24068

Table 1. Socio-demographic data of research population.

\begin{tabular}{|c|c|c|}
\hline Age groups & $\mathbf{N}(\%)$ & $\mathbf{N}$ \\
\hline until 19 years & 25,2 & 127 \\
\hline $20-25$ & 52,5 & 264 \\
\hline $26-30$ & 10,7 & 54 \\
\hline $31-35$ & 5,8 & 29 \\
\hline $36-40$ & 3,0 & 15 \\
\hline $41-45$ & 1,6 & 8 \\
\hline Over 50 years & 1,2 & 6 \\
\hline Genre & $\mathbf{N}(\%)$ & $\mathbf{N}$ \\
\hline Female & 85,7 & 431 \\
\hline Male & 14,3 & 72 \\
\hline Graduation stages & $\mathbf{N}(\%)$ & $\mathbf{N}$ \\
\hline $1^{\circ}-4^{\circ}$ & 51,3 & 258 \\
\hline $5^{\circ}-8^{\circ}$ & 35,8 & 180 \\
\hline $9^{\circ}-12^{\circ}$ & 12,9 & 65 \\
\hline Undergraduated courses & $\mathbf{N}(\%)$ & $\mathbf{N}$ \\
\hline Agrarian Sciences & 0,2 & 1 \\
\hline Biological Sciences & 8,0 & 40 \\
\hline Health Sciences & 78,5 & 395 \\
\hline Exact and Earth Sciences & 1,4 & 7 \\
\hline Humanities, letters and arts & 8,2 & 41 \\
\hline Social Sciences & 1,8 & 9 \\
\hline Engineering / Technologies & 2,0 & 10 \\
\hline Individuals diagnosed with a mood disorder & $\mathbf{N}(\%)$ & $\mathbf{N}$ \\
\hline Yes & 37,8 & 190 \\
\hline No & 62,2 & 313 \\
\hline Civil status & $\mathbf{N}(\%)$ & $\mathbf{N}$ \\
\hline Married or lives together & 20,1 & 101 \\
\hline Stable relationship( does not live together) & 15,5 & 78 \\
\hline Single & 63,2 & 318 \\
\hline Widowed & 0,20 & 1 \\
\hline Other & 0,9 & 5 \\
\hline Lives with & $\mathbf{N}(\%)$ & $\mathbf{N}$ \\
\hline Friend/colleagues & 1,9 & 10 \\
\hline Husband and children & 7,5 & 38 \\
\hline Father/Mother & 62,4 & 314 \\
\hline Only with husband & 10,7 & 54 \\
\hline
\end{tabular}


Research, Society and Development, v. 10, n. 16, e548101624068, 2021

(CC BY 4.0) | ISSN 2525-3409 | DOI: http://dx.doi.org/10.33448/rsd-v10i16.24068

\begin{tabular}{|c|c|c|}
\hline Only with children & 1,4 & 7 \\
\hline Alone & 4,6 & 23 \\
\hline Other & 11,3 & 57 \\
\hline
\end{tabular}

Legend: A total of 503 undergraduate students from private educational institutions, distributed throughout Brazil, participated in this study. Here was described data of socio-demographic descriptions. In the table it is possible to have information about age, gender, marital status, graduation stages, courses, and if the individual already had a diagnosis of a mood disorder. Source: Authors (2021).

\subsection{Symptoms and Psychological Impact of social isolation}

The prevalence of symptoms of anxiety, depression, and stress was verified by the DASS-21 scale. It was possible to observe that an average of almost $70 \%$ of the participants had symptoms of stress, anxiety, or depression. A very relevant fact was that of the people who reported having some type of mood disorder $63 \%$ had severe scores of anxiety symptoms, $41 \%$ depression, and 37\% stress (Figure 2). Pointing out a great concern because, in addition to presenting one or more symptoms of mood disorders, the vast majority had extremely severe scores.

Figure 2. Symptoms and Psychological Impact of social isolation by the Anxiety, Depression and Stress Scale DASS-21 in individuals diagnosed with a mood Score of extremely severe previously

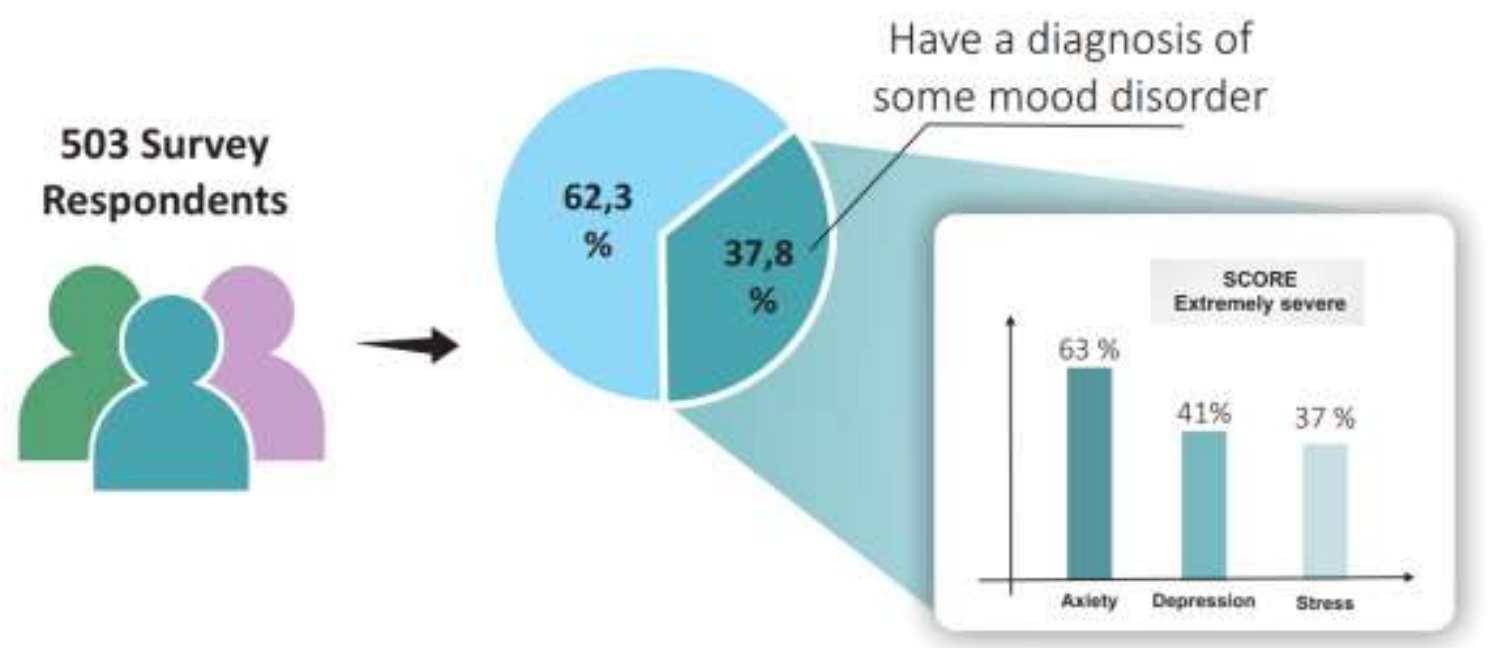

Legend: The scheme shows the symptoms extremely severe in individuals who reported having some mood disorder previously. To identify the prevalence of anxiety, depression, and stress symptoms, the DASS-21 scale was used. Source: Authors (2021).

In all groups of symptoms (stress, anxiety and depression) there was a higher prevalence of extremely severe symptoms. An important point was that in individuals who reported that they had or had been diagnosed with a mood disorder, the percentage of individuals who had extremely severe symptoms was higher than in the general assessment, without distinguishing those who had already had a disorder. These data can be seen at the bottom of Table 2 . 
Research, Society and Development, v. 10, n. 16, e548101624068, 2021

(CC BY 4.0) | ISSN 2525-3409 | DOI: http://dx.doi.org/10.33448/rsd-v10i16.24068

Table 2. Symptoms and Psychological Impact of social isolation by the Anxiety, Depression and Stress Scale DASS-21.

\begin{tabular}{|c|c|c|c|c|c|c|}
\hline & \multicolumn{2}{|c|}{ Anxiety } & \multicolumn{2}{|c|}{ Depression } & \multicolumn{2}{|c|}{ Stress } \\
\hline Scores & $\mathbf{N}(\%)$ & $\mathbf{N}$ & $\mathbf{N}(\%)$ & $\mathbf{N}$ & $\mathbf{N}(\%)$ & $\mathbf{N}$ \\
\hline Normal & 32,0 & 161 & 29,6 & 149 & 31,0 & 156 \\
\hline Light & 3,8 & 19 & 12,7 & 64 & 10,9 & 55 \\
\hline Moderate & 17,7 & 89 & 20,3 & 102 & 15,9 & 80 \\
\hline Severe & 8,5 & 43 & 9,3 & 47 & 20,3 & 102 \\
\hline Extremely severe & 38,0 & 191 & 28,0 & 141 & 21,9 & 110 \\
\hline & \multicolumn{2}{|c|}{ Anxiety } & \multicolumn{2}{|c|}{ Depression } & \multicolumn{2}{|c|}{ Stress } \\
\hline Scores & $\mathbf{N}(\%)$ & $\mathbf{N}$ & $\mathbf{N}(\%)$ & $\mathbf{N}$ & $\mathbf{N}(\%)$ & $\mathbf{N}$ \\
\hline Normal & 11,1 & 21 & 16,8 & 32 & 13,7 & 26 \\
\hline Light & 3,2 & 6 & 8,9 & 17 & 10,0 & 19 \\
\hline Moderate & 15,3 & 29 & 23,2 & 44 & 14,7 & 28 \\
\hline Severe & 7,4 & 14 & 10,0 & 19 & 23,7 & 45 \\
\hline Extremely severe & 63,2 & 120 & 41,1 & 78 & 37,9 & 72 \\
\hline
\end{tabular}

Legend: Each respondent was evaluated by DASS-21 in general. The second part of the table showed scores of DASS-21 presented by a specific group that previously related a diagnosis to any mood disorders. Source: Authors (2021).

It has been increasingly demonstrated that symptoms of anxiety, depression and stress can be concomitantly present. Therefore, we evaluated the raw data on the presence of symptoms that appeared concomitantly in each respondent as demonstrated in Figure 3. Of the 503 respondents, we evaluated those who had extremely severe symptoms. Of these, they scored extremely severely for anxiety (191), depression (141) and stress (110). The data were crossed and it was possible to observe that 76 people had an extremely severe score for anxiety, depression and stress concomitantly (Figure 3B). In the sequence, it was possible to observe 4 of these individuals had at the same time extremely severe symptoms of anxiety and depression (Figure 3C). We also observed that 42 respondents had extremely severe scores for depression and stress (Figure 3D) and finally 18 had high scores for symptoms of anxiety and stress (Figure 3E). 
Figure 3. Score of extremely severe concomitant

A
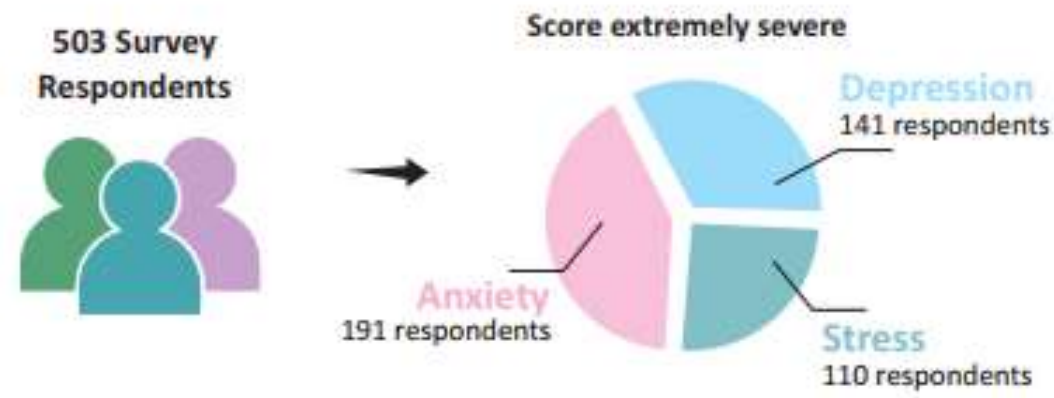

B

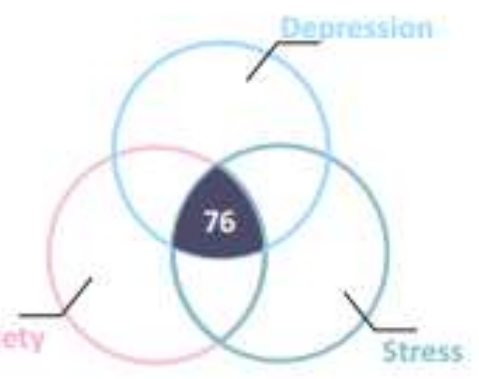

Score extremely severe to anxiety, depression and stress concomitant

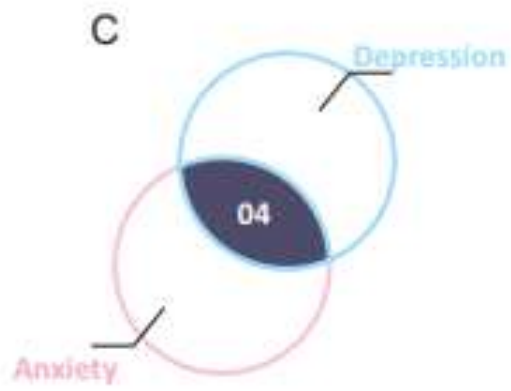

Score extremely severe to anxiety, and depression concomitant
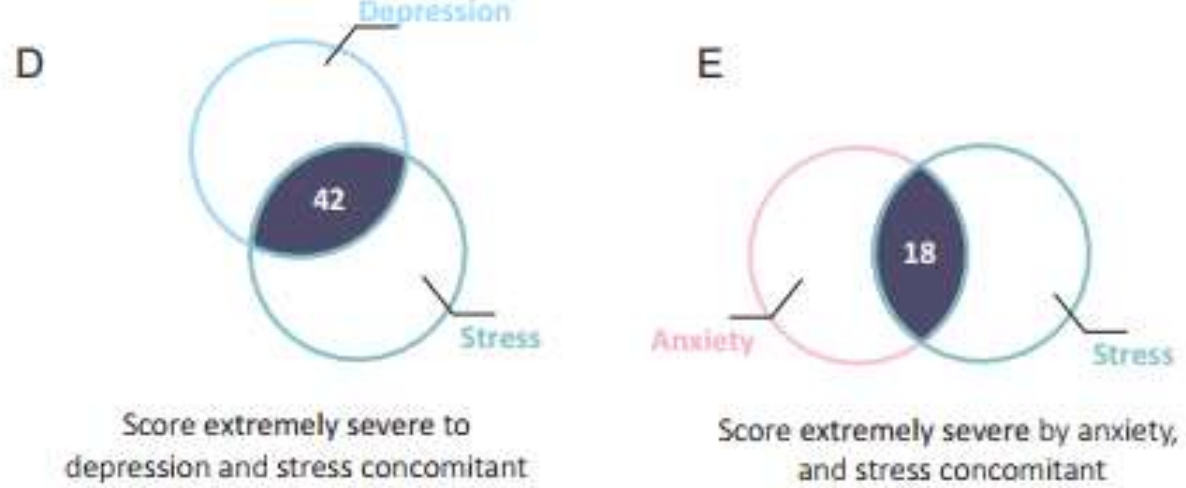

Legend: It has been demonstrated that symptoms of anxiety, depression, and stress can be concomitantly present. In this session it was evaluated the raw data on the presence of symptoms that appeared concomitantly in each respondent. Source: Authors (2021).

\subsection{Relationship between sociodemographic data and symptoms of stress, anxiety and depression}

The prevalence of symptoms of anxiety, depression and stress was correlated with sociodemographic data as demonstrated in Table 3. Regarding gender, there was a higher prevalence, in female students, of symptoms of stress, anxiety and depression. In addition, there was a higher prevalence of severe and extremely severe symptoms of depression (30\%), anxiety (41\%) and stress (23\%) in females when compared to males.

Moreover, it was possible to observe a negative correlation of anxiety symptoms about age. The younger the age, the higher the anxiety scores. The table below shows all the data evaluated, in its gross value and as a percentage. Separated by gender, age, and other sociodemographic information (Table 3).

Table 3. Correlation of Socio-demographic data, symptoms and Psychological Impact of social isolation by DASS-21 
Research, Society and Development, v. 10, n. 16, e548101624068, 2021

(CC BY 4.0) | ISSN 2525-3409 | DOI: http://dx.doi.org/10.33448/rsd-v10i16.24068

Table 3. Correlation of Socio-demographic data, symptoms and Psychological Impact of social isolation by DASS-21.

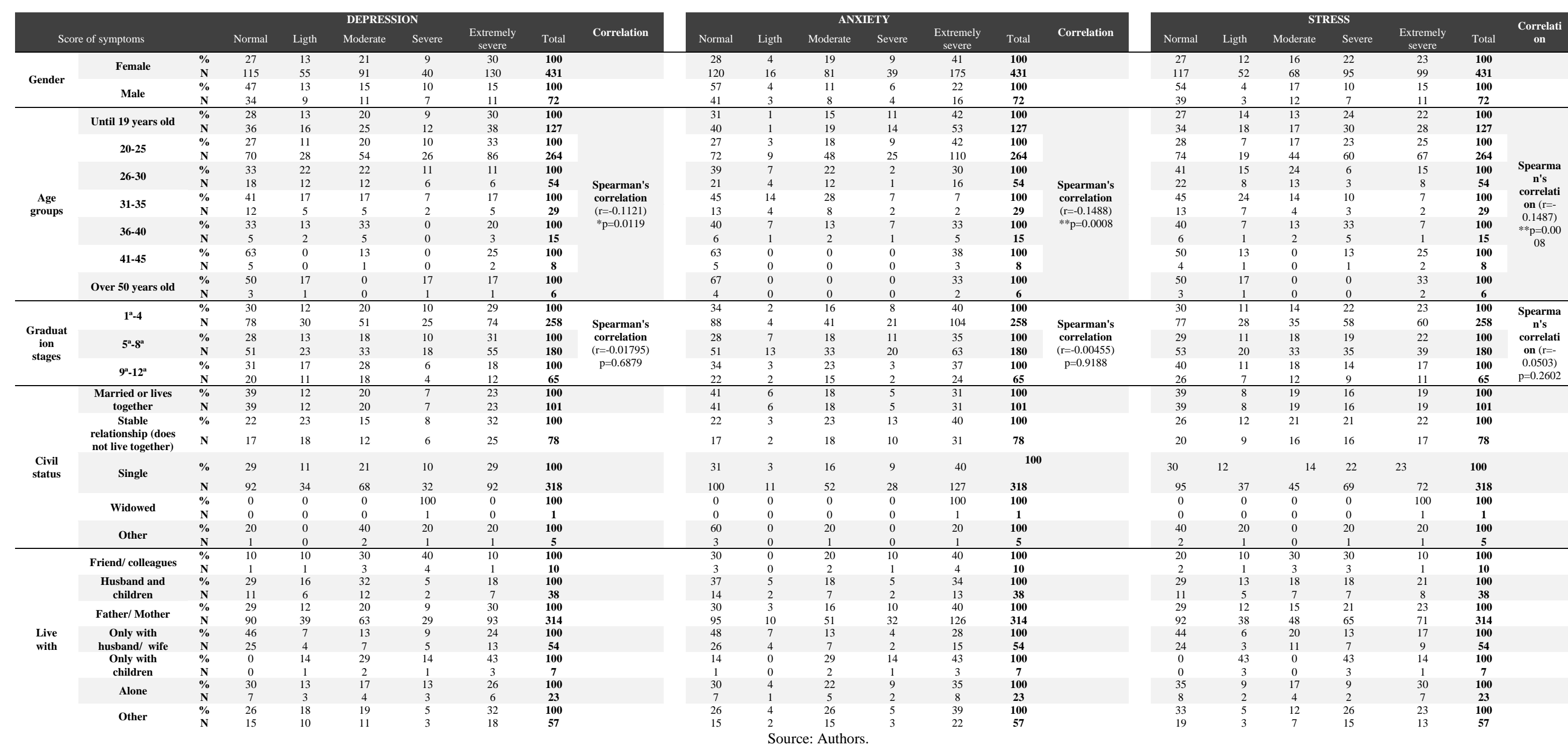




\section{Discussion}

The present study elucidates relevant data on the mental health of university students participating in the research, especially regarding the presence of symptoms of depression, anxiety and stress. By adding results of the severe and extremely severe scores, a proportion of $37 \%$ of participants in this condition was identified with depression, $47 \%$ with anxiety and $42 \%$ with stress. The presence of symptoms such as anxiety and depression are recurrent facts among higher education students (Soares et al., 2011), a reality that intensified during the pandemic period (Coelho et al., 2020; Gundim et al., 2021). The many changes and new demands concerning this stage of life and the consequent need for adaptation, end up having a negative impact on the mental health of university students (Ariño \& Bardagi, 2018). Thus, it is clear that stressful conditions typical of this phase can contribute to the emergence of mental health problems, as well as to their maintenance and/or aggravation (Carpena \& Menezes, 2018).

Problems related to the students' mental health were enhanced by the pandemic situation, which ended up generating a feeling of insecurity and a lack of perspective for the future. This association between mental health, insecurity and uncertainty about the future among university students was identified in students from China (Cao et al., 2020; Wang et al., 2020), the first country affected by the COVID-19 pandemic. Among participants in the study by Cao et al. (2020) a correlation between anxiety and concern for the future was demonstrated. Similarly, the participants of the study by Wang et al. (2020) demonstrated that uncertainty about the future had negative impacts on mental health.

In Portugal, a study showed a significant increase in anxiety, depression and stress symptoms among university students in the pandemic period compared to the previous period (Maia \& Dias, 2020). In the present study, it was not possible to make this comparison at different times, however, based on what was observed in other studies (Cao et al., 2020; Gundim et al., 2021; Maia \& Dias, 2020; Wang et al., 2020) it is assumed that the pandemic period can generate or aggravate mental health problems also among the participants of this research.

Wang et al. (2020) demonstrated that the impacts induced by the pandemic were predominantly from moderate to severe for symptoms of anxiety, depression and stress. In another study carried out in Brazil (Coelho et al., 2020) it was also verified that students' mental health worsened during the pandemic period. Participants reported difficulties with the new routine and social distancing, in addition to difficulties in dealing with the unknown, which triggered feelings of fear and anxiety.

The mental illness of university students is revealed by the condition of stress, symptoms of anxiety, depression, feelings of incapacity in the face of social isolation, various concerns, irritability, eating disorders and loss of willingness to perform activities that were previously pleasurable (Gundim et al., 2021). Coelho et al. (2020) add that fear, insecurity, isolation, among other factors, can lead to stress, anxiety and bring changes to the students' life routine. In fact, during a pandemic, people experience several concerns, frustrations and insecurities about the future. In addition, the limitation of mobility and social isolation imposed by quarantine negatively affects mental health (Silva et al., 2020). Some possible causes that impact on students' mental health, factors such as disruption of academic routine, distancing from friends and colleagues, concern with academic trajectory and professional future stand out (Gundim et al., 2021).

Another fact that should be highlighted about the data of this study was the concomitant presence of the extremely severe score for depression, anxiety and stress among 76 participants, as well as the concomitant presence of such a score for depression and stress among 42 participants and 18 for anxiety and depression. These data reveal the complexity and intensity of mental health problems experienced by many of the participants, which may have been aggravated during the pandemic.

The pandemic situation generates a series of stressors that can produce or potentiate mental illness (Silva et al., 2020). In fact, patients with some mental illness were more likely to be affected by the consequences of COVID-19 specifically 
concerning the impacts on mental health. Authors highlighted the occurrence of feelings of sadness, suffering and grief and warned that with the expansion of COVID-19 around the world, the incidence of suffering and psychiatric mormities in different countries and populations (Li et al., 2020).

In the present study, we also obtained socio-demographic data including age and gender, which we correlated to symptoms of depression, anxiety and stress. The age group with the highest representation of participants with extremely severe symptoms of depression, anxiety and stress was between 20 and 25 years followed by the cycle of up to 19 years. This data elucidates a reality of suffering experienced by these young and emerging adults that may be linked to several situations of pressure, anguish and uncertainty.

The emerging adult, often considered from 18 to 24 years old, represents the phase of the life cycle between adolescence and adulthood, a period of transition with several challenges. Nowadays, there is a higher qualification requirement for insertion in the job market, which leads young people to extend their professional training, which, in most cases, results in family economic dependence for a longer time. It is a period of representative psychological and social transformations, since the young adult finds himself in the ambivalence of a phase that represents the opening to several possibilities, but also carries the typical responsibilities and obligations of adult life (Andrade, 2010).

Mahmoud (2011) highlights that psychological distress in university students is related to the stage of transient development experienced by many of them. The research identified that participants between 20 and 24 years of age were the most prone to symptoms of depression, anxiety and stress. Likewise, in Brazil, a study performed by Padovani et al. (2014) found that university students are more vulnerable to mental illness, with recurrent symptoms of depression, anxiety and stress. The mental health problems among university students worsened during the pandemic since it increase anxiety, symptoms of post-traumatic stress; acute stress; depressive symptoms; feelings of anger, fear, sadness, frustration, guilt, helplessness, loneliness; low concentration; mental confusion; exhaustion; reduced professional performance; insomnia; fear about the present and the future; alcohol abuse and suicide risk (Brooks et al., 2020). Such symptoms are associated with high drains on the DASS-21 scale of the participants of this research, especially of the public up to 25 years old.

It was also observed in the present study, a notable difference in the scores of depression, anxiety and stress between men and women, which are the most susceptible to mental illness. This fact highlights a recurring reality and has already been identified in other studies (Bayam \& Bilgel, 2008; Mahmoud, 2011; Maia \& Dias, 2020) and suggests that despite all the advances already achieved, the female condition today is still permeated by difficulties related to gender. In line with our results, Bayram and Bilgel (2008) found that among university students, women obtained the highest drains on the DASS-21 scale for anxiety and stress, whereas depression there was no significant difference between men and women. Maia and Dias (2020) found that women before and during the pandemic had higher scores on the anxiety and stress subscales.

Although women have been conquering space in work and studies, it does not exempt them from the historically feminine demands such as care for the home and family, it is this overload of functions of the woman that justifies, to a large extent, many of her illnesses. It is not, therefore, a question of a physiological order of your sex, but social and cultural aspects (Beauvoir, 2019). Parents, teachers and colleagues do not encourage girls to pursue certain careers, notably that of technological areas. On the other hand, there is an incentive for young women to choose professions related to care and education, thus demonstrating a gender perspective implicit in their choice and professional practice (Bourdieu, 2019). There are many factors related to the change process that involves the condition of women in society, of all of them, however, the main one is the school institution that, by enabling the increase of women's access to academic education, ends up enabling their independence (Bourdieu, 2019). In this sense, the importance of researching in this context is highlighted to enable strategies to reduce inequalities.

Given the difficulties imposed by the pandemic and the impacts on mental health, especially among university 
students, it is necessary to implement strategies and actions aimed at reducing the negative effects (Coelho et al., 2020). In this context, in order to minimize the negative effects caused by the pandemic and social isolation, the World Health Organization (WHO, 2020) recommended that people maintain their routine, or, if necessary, adapt it to new circumstances; acknowledge and embrace your fears, needs and feelings; engage in physical activities and other activities that bring comfort and relief; ensure a regular sleep routine and good nutrition; rescue strategies already used in times of difficulty that provided well-being; have good working conditions ensuring breaks and maintenance of contacts; participate in collective care actions that strengthen the feeling of social belonging; (re)organize plans and projects; seek information from reliable sources and reduce the time of exposure to information about the pandemic; avoid the use of alcohol and other drugs; seek professional help when necessary and keep the social and affective network active with frequent contact, even if virtually (Fiocruz, 2020; WHO, 2020).

A limitation of the present study was that the research was performed after COVID-19 pandemic, and data before that was not requested. For this reason, it wasn't possible to compare the effects of stress, anxiety, or depression before and after social isolation.

\section{Conclusion}

The participants profile observed in the present study corresponds to the portrait of the Brazilian higher education students, that is, the conciliation between work and study. The predominant age corresponds to the so-called emerging adult phase and the prevalence of women participating in the study stands out, which can, to a large extent, explain the health sciences being the area of the greatest participation since, historically, the courses of health are predominantly characterized as women's courses. Finally, although we cannot compare the same individuals before and after social isolation, it is possible to speculate that insecurity, fear and social isolation, which are associated to COVID-19 pandemic, probably increased the susceptibility of students to present symptoms of anxiety, depression and stress.

Therefore, the results obtained in this work are extremely important since it allowed the identification of symptoms related to mood disorders within the university context during the period of social isolation. From this data collection, it is possible to plan the creation of intervention and prevention strategies for the symptoms of mood disorders within the current panorama to improve the quality of life of university students.

\section{Acknowledgments}

We would like to thank Unisociesc Jaraguá do Sul for the opportunity to perform the present study.

\section{References}

Adewuya, A. O., Ola, B. A., Aloba, O. O., Mapayi, B. M. \& Oginni, O. O. (2006). Depression amongst Nigerian university students. Prevalence and sociodemographic correlates. Soc Psychiatry and Psychiatric Epidemiology 41(8): 674-678.

Ahmed, M. Z., Ahmed, O., Aibao, Z., Hanbin, S., Siyu, L. \& Ahmad, A. (2020). Epidemic of COVID-19 in China and Associated Psychological Problems. Asian J Psych; 51:102092.

Andrade, C. (2010). Transição para a idade adulta: Das condições sociais às implicações psicológicas. Análise Psicológica, 28(2), 255-267. https://doi.org/10.14417/ap.279

Ariño, D. O. \& Bardagi, M. T. (2018). Relação entre Fatores Acadêmicos e a Saúde Mental de Estudantes Universitários. Psicologia em Pesquisa, 12(3), 4452. $10.24879 / 2018001200300544$

Barros, M. B. A., Lima, M. G., Ceolin, M. F., Zancanella, E. \& Cardoso, T. A. M. O. (2019). Quality of sleep, health status and subjective well-being in a population-based study. Ver Saúde Pública, 2019;53:82. doi.org/10.11606/s1518-8787.2019053001067

Bayram, N. \& Bilgel, N. (2008). The prevalence and socio-demographic correlations of depression, anxiety and stress among a group of university students. Social Psychiatry and Psychiatric Epidemiology, 43, 667-672. https://doi.org/10.1007/s00127-008-0345-X 
Beauvoir, S. (2019). O segundo sexo. (5a ed.). Nova Fronteira.

Borges, K. M., Figueiredo, F. W. S. \& Souto, R. P. (2017). Night eating syndrome and emotional states in university students. Journal Of Human Growth And Development, 27:3, 332-139.

Bourdieu, P. (2019). A dominação masculina. (16a ed.). Bertrand Brasil.

Brasil. Ministério da Saúde (MS). Coronavírus COVID-19. https://coronavirus.saude.gov.br/

Brasil. Ministério da Saúde (MS). Conselho Nacional de Saúde. Resolução n. $466 \quad$ de $12 \quad$ de Dezembro de 2012. http://conselho.saude.gov.br/resolucoes/2012/Reso466.pdf

Brooks, S. K., Webster, R. K., Smith, L. E., Woodland, L., Wessely, S., Greenberg, N., \& Rubin, G.J. (2020). The psychological impact of quarantine and how to reduce it: rapid review of the evidence. Lancet, 395. 912-920. https://doi.org/10.1016/S0140-6736(20)30460-8

Cao, W., Fang, Z., Hou, G., Han, M., Xu., X., Dong, J., \& Zheng, J. (2020). The psychological impact of the COVID-19 epidemic on college students in China. Psychiatry Research, 287. 10.1016/j.psychres.2020.112934

Carpena, M. X. \& Menezes, C. B. (2018). Efeito da Meditação Focada no Estresse e Mindfulness Disposicional em Universitários. Psicologia: Teoria e Pesquisa, 34, 1-12.

Cavestro, J. M. \& Rocha, F. L. (2006). Prevalência de depressão entre estudantes universitários. Jornal Brasileiro de Psiquiatria, 55 (4), $264-267$.

Coelho, A. P. S., Oliveira, D. S., Fernandes, E. T. B. S., Santos, A. L. S., Rios, M. O., Fernandes, E. S. F., \& Fernandes, T. S. S. (2020). Saúde mental e qualidade do sono entre estudantes universitários em tempos de pandemia da COVID-19: experiência de um programa de assistência estudantil. Research, Society and Development, 9(9), 1-14. http://dx.doi.org/10.33448/rsd-v9i9.8074

Craske, M. G., Stein, M. B., Eley, T. C., Milad, M. R., Holmes, A., Rapee, R. M. \& Wittchen, H-U. (2017). Anxiety disorders. Nat Rev Dis Primers 3: 1702.

Dong, L. \& Bouey, J. (2020). Public Mental Health Crisis during COVID-19 Pandemic, China. Emerging Infectious Diseases, $26(7), 202$.

DuailibI, K., Silva, A. \& Jubara, C. (2014). Como diagnosticar e tratar depressão. Revista Brasileira de Medicina.de Família e Comunidade, 71:12, 23-31.

Eisenberg, D., Gollust, S. E., Golberstein, E. \& Hefner, J. L. (2007). Prevalence and correlates of depression, anxiety, and suicidality among university students. Am J Orthopsychiatry 77(4): 534-542.

Fundação Oswaldo Cruz. (2020). Saúde Mental e Atenção Psicossocial na Pandemia COVID-19: recomendações gerais. https://www.fiocruzbrasilia.fiocruz.br/wp-content/uploads/2020/04/Sa\%c3\%bade-Mental-e-Aten\%c3\%a7\%c3\%a3o-Psicossocial-na-Pandemia-Covid-19recomenda\%c3\%a7\%c3\%b5es-gerais.pdf

Huang, Y. \& Zhao, N. (2020). Generalized anxiety disorder, depressive symptoms and sleep quality during COVID-19 outbreak in China: a web-based crosssectional survey. Psychiatry Research 288112954.

Gil, A.C. (2002). Como Elaborar Projetos de Pesquisa. (4a ed.), Atlas, 176.

Gundim, V. A., Encarnação, J. T., Santos, F. C., Santos, J. E., Vasconcellos, E. A. \& Souza, R. C. (2021). Saúde mental de estudantes universitários durante a pandemia de covid-19. Revista Baiana de Enfermagem, 35, 1-14. http://dx.doi.org/10.18471/rbe.v35.37293

Jung, S. J. \& Jun, J. Y. (2020). Mental Health and Psychological Intervention Amid COVID-19 Outbreak: Perspectives from South Korea. Yonsei Med J 61(4): 271-272.

Li, W., Yang, Y., Liu, Z., Zhao, Y., Zhang, Q., Zhang, L., Cheung, T. \& Xiang, Y. (2020). Progression of Mental Health Services during the COVID-19 Outbreak in China. International Journal of Biological Sciences, 16(10), 1732 - 1738. 10.7150/ijbs.45120

Mahmoud, J. S. R. (2011). The relationship of anxiety, coping, thinking style, life satisfaction, social support, and selected demographics among young adult college students. University of Kentucky Doctoral Dissertations. 128. https://uknowledge.uky.edu/gradschool_diss/128

Maia, B. R. \& Dias, P. C. (2020). Ansiedade, depressão e estresse em estudantes universitários: o impacto da COVID-19. Estudos de Psicologia (Campinas), 37, 1-8. http://dx.doi.org/10.1590/1982-0275202037e200067

Barros, M. B. A., Lima, M. G., Malta, D. C., Szwarcwald, C. L., Azevedo, R. C. S., Romero, D., \& Gracie, R. (2020). Report on sadness/depression, nervousness/anxiety and sleep problems in the Brazilian adult population during the COVID-19 pandemic. Epidemiol. Serv. Saude, Brasília, 29 (4):e2020427.

Martins, B. G., Silva, W. R., Maroco. J., \& Campos, J. A. D. B. (2019). Escala de Depressão, Ansiedade e Estresse: propriedades psicométricas e prevalência das afetividades. Jornal Brasileiro de Psiquiatria, 68: 1, 32-41.

Nyer, M., Farabaugh, A., Fehling, K., Soskin, D., Holt, D., Papakostas, G. I. \& Mischoulon, D. (2013). Relationship between sleep disturbance and depression, anxiety, and functioning in college students. Depress Anxiety. 2014; 30:1-14.

Ornell, F., Schuch, J. B., Sordi, A. O. \& Kessler, F. H. P. (2020). "Pandemic fear" and COVID-19: mental health burden and strategies. Braz J Psychiatry.42(3). 10.1590/1516-4446-2020-0008.

Padovani, R. C., Neufeld, C. B., Maltoni, J., Barbosa, L. N. F., Souza, W. F., Cavalcanti, H. A. F. \& Lameu, J. N. (2014). Vulnerabilidade e bem-estar psicológicos do estudante universitário. Revista Brasileira de Terapias Cognitivas, 10(1), 2-10. http://dx.doi.org/10.1590/1982-0275202037e200067. 
Shigemura, J., Ursano, R. J., Morganstein, J. C., Kurosawa, M. \& Benedek, D. M. (2020). Public responses to the novel 2019 coronavirus (2019-nCoV) in Japan: mental health consequences and target populations. Psychiatry Clin Neurosci;74(4):281-2. 10.1111/ pcn.12988

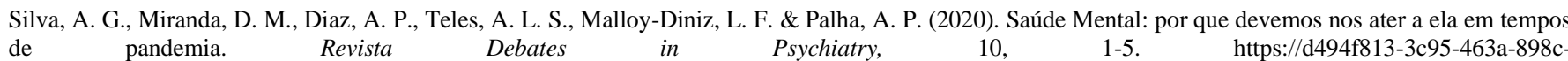
ea1519530871.filesusr.com/ugd/c37608_a876b4f599c3485987f58a81fcf9483a.pdf.

Soares, A. B., Mello, T. V. S., \& Baldez, M. O. M. (2011). Vivências acadêmicas em estudantes universitários do Estado do Rio de Janeiro. Interação em Psicologia, v. 15, n. 1, p.59-69. http://dx.doi.org/10.5380/psi.v15i1.16049

Vignola, R. C. B. \& Tucci, A. M. (2014). Adaptation and validation of the depression, anxiety and stress scale (DASS) to Brazilian Portuguese. Journal of Affective Disorders, 155, 104-109.

Wang, C., Pan, R., Wan, X., Tan, Y., Xu, L., Ho, C. S. \& Ho, R. C. (2020). Immediate Psychological Responses and Associated Factors during the Initial Stage of the 2019 Coronavirus Disease (COVID-19) Epidemic among the General Population in China. International Journal of Environmental Research and Public Health, 17(5), 1-25. https://doi.org/10.1007/s00127-008-0345-x 10.3390/ijerph17051729

Wang, C., Cheng, Z., Yue, X. G. \& McAleer, M. (2020). Risk Management of COVID-19 by Universities in China. Journal Risk and Financial Management, 13(2), 1-6. 10.3390/jrfm13020036

Whiteford, H. A., Degenhardt, L., Rehm, J., Baxter, A. J., Ferrari, A. J., Erskine, H. E., \& Vos, T. (2013). Global burden of disease attributable to mental and substance use disorders: findings from the Global Burden of Disease Study 2010. Lancet, 9 nov. 2013;382(9904):1575-1586.

WHO. (2020). Mental health and psychosocial considerations during COVID-19 outbreak. https://www.who.int/docs/default-source/coronaviruse/mentalhealth-considerations.pdf?sfvrsn=6d3578af_2

Wilder-Smith, A., \& Freedman, D. O. (2020). Isolation, quarantine, social distancing and community containment: pivotalrole for old-style public health measures in the novel coronavirus (2019-nCoV) outbreak. J Travel Med; 27(2):020.

Wong, M. L., Lau, E. Y. Y., Wan, J. H. Y., Cheung, S. F., Hui, C. H. \& Mok, D. S. Y. (2013). The interplay between sleep and mood in predicting academic functioning, physical health and psychological health: A longitudinal study. J Psychosom Res.; 74:271-7. 10.1016/j.jpsychores.2012.08.014 PMID: 23497826.

Xiang, Y-T., Yang, Y., Li, W., Zhang, L., Zhang, Q., Cheung, T., \& Ng, C. H. (2020). Timely mental health care for the 2019 novel coronavirus outbreak is urgently needed. Lancet Psych; 7(3):228-229. 